\title{
PENGARUH EFIKASI DIRI DAN KONTROL DIRI TERHADAP PROKRASTINASI AKADEMIK PADA MAHASISWA UNIVERSITAS 17 AGUSTUS 1945 SAMARINDA
} THE EFFECT OF SELF EFFICACY AND SELF CONTROL ON ACADEMIC PROCRASTINATION AT STUDENTS UNIVERSITY 17 AUGUST 1945 SAMARINDA Mita wulandari $^{(1)}$, Siti Khumaidatul Umaroh ${ }^{(2)}$, Silvia Eka Mariskha ${ }^{(3)}$

Fakultas Psikologi Universitas 17 Agustus 1945 Samarinda $^{(1)}$, Fakultas Psikologi Universitas 17 Agustus 1945 Samarinda $^{(2)}$, Fakultas Psikologi Universitas 17 Agustus 1945 Samarinda $^{(3)}$ E-mail: mitawulandari15@yahoo.com ${ }^{(1)}$, sitikhumaidatulumaroh@yahoo.co.id ${ }^{(2)}$, mariskha87@gmail.com ${ }^{(3)}$

\begin{abstract}
Abstrak : Penelitian ini dilakukan dengan tujuan untuk mengetahui secara empiris pengaruh self efficacydan self control terhadap prokrastinasi akademik. Penelitian ini melibatkan 320 mahasiswa di Universitas 17 Agustus 1945 Samarinda. Penetapan sampel penelitian menggunakan teknik proportionate stratified random sampling. Data penelitian diperoleh menggunakan tiga jenis skala yaitu self efficacy, self control dan prokrastinasi akademik. Data penelitian dianalisis menggunakan regresi linear berganda. Berdasarkan hasil analisis diketahui bahwa self efficacydan self control berpengaruh negatif terhadap prokrastinasi akademik dengan nilai sig $=0,000<0,05$. Pengaruh self efficacydan self control terhadap prokrastinasi akademik ditunjukkan oleh nilai $\mathrm{R}^{2}$ sebesar 0,400 , yang berarti bahwa variasi prokrastinasi akademik dipengaruhi oleh variabel self efficacydan self control sebesar $40 \%$. Dalam hal ini self efficacymempengaruhi prokrastinasi akademik sebesar 24,9\% sementara self control mempengaruhi prokrastinasi akademik sebesar $15,1 \%$.
\end{abstract}

Kata Kunci : Self Efficacy, Self Control, Prokrastinasi Akademik

Abstract: This research was conducted in order to determine empirically the effect of self efficacyand self comtrol on academic procrastination. Research involved 320 students of University 17 August 1945 Samarinda. Field using proportionate stratified random sampling technique. The research data were obtained using scale self efficacy, self control and academic procrastination. The research data were analyzed using multiple linear regression techniques. Based on the results of the analysis it is known that self efficacyand self control has a negative effect on academic procrastination with a value of sig $=0,000$ $<0.05$. The effect given by the variable self efficacyand self control for academic procrastination is shown by the $R^{2}$ value of 0.400 , wich means that the variation of academic procrastination effected $40 \%$ by the self efficacyand self control variable. In this case self efficacyaffects academic procrastination by $24,9 \%$. While self control affects academic procrastination by $15,1 \%$.

Keywords: Self efficacy, Self control, Academic procrastination 


\section{PENDAHULUAN}

Mahasiswa sebagai seseorang yang menuntut ilmu di perguruan tinggi, dituntut untuk dapat menjalani proses akademik agar mampu berprestasi secara optimal. Namun, mahasiswa sering kali dihadapkan dengan perkuliahan, baik itu tugas akademik ataupun non akademik. Tugas akademik yaitu jenis tugas formal yang berhubungan dengan akademik, misalnya tugas kuliah seperti membuat laporan/paper, menyiapkan powerpoint untuk persentasi tugas kuliah dan membaca. Sedangkan tugas non akademik adalah jenis tugas yang berhubungan dengan kegiatan sehari-hari, misalnya pekerjaan rumah, mengikuti organisasi, dan bekerja (Ferrari, dalam Chintia, 2017).

Banyaknya tugas kuliah menjadi penyebab konsentrasi mahasiswa berkurang terhadap tugastugas yang seharusnya diselesaikan tepat sehingga justru banyak mahasiswa yang menunda-nunda untuk menyelesaikannya. Kondisi seperti ini disebut dengan prokrastinasi dalam bidang akademik. Solomon dan Rothblum (dalam Gufron \& Risnawati, 2010) menjelaskan bahwa suatu penundaan dikatakan sebagai prokrastinasi apabila penundaan itu dilakukan pada tugas yang penting, dilakukan berulangulang secara sengaja, menimbulkan perasaan tidak nyaman, serta secara subyektif dirasakan oleh prokrastinator.

Prokrastinasi akademik penting untuk diteliti karena berpotensi menghambat proses pembelajaran dan prokrastinasi akademik yang dilakukan mahasiswa akan menimbulkan dampak negatif pada prestasi yang akan diraih (You, 2015). Prokrastinasi akademik pada mahasiswa dapat menghambat mereka untuk menyelesaikan suatu mata kuliah tertentu. Semakin lama mereka menunda maka semakin lama pula mereka untuk menyelesaikan tugas mata kuliah tertentu (Pratiwi \& Sawitri, 2015). Prawitasari(2012) mengungkapkan bahwa penundaan-penundaan yang terus-menerus dilakukan akan berakibat fatal, misalnya kegagalan memperoleh gelar sarjana, dan keterlambatan penyelesaian kuliah sehingga terjadi biaya penambahan kuliah. Secara materiil penundaan sering kali diikuti oleh perasaan bersalah, marah dan tidak berguna.
Dalam beberapa penelitian terdahulu yang dilakukan oleh Avico dan Mujidin (2014) menunjukkan bahwa konformitas yang tinggi dapat meningkatkan individu untuk melakukan prokrastinasi akademik sebaliknya jika konformitas rendah maka prokrastinasi akademik pada mahasiswa juga rendah. Selain konformitas, pengasuhan orang tua juga dapat mempengaruhi sesorang untuk melakukan prokrastinasi akademik, hal ini dibuktikan dengan penelitian yang dilakukan oleh Rosani \& Indrawati (2018) bahwa terdapat hubungan positif yang signifikan antara pola asuh otoriter dengan prokrastinasi akademik pada mahasiswa. Semakin positif persepsi pola asuh otoriter terhadap orangtua maka akan semakin tinggi prokrastinasi akademik yang dilakukan mahasiswa begitupun sebaliknya. Hasil penelitian Kadi (2016) terdapat hubungan kepercayaan diri dan self regulated learning terhadap prokrastinasi akademik pada Mahasiswa. Mahasiswa dengan kepercayaan diri yang rendah maka prokrastinasi akademik semakin tinggi artinya individu kurang yakin dengan pilihan dan kemampuan dalam mengerjakan tugas, begitupun sebaliknya mahasiswa yang memiliki kepercayaan diri yang tinggi maka prokrastinasi semakin rendah artinya individu yakin dengan pilihan dan kemampuan dalam mengerjakan tugas.

Tingkat keyakinan yang dimiliki seseorang dapat mendorongnya untuk meningkatkan kemampuan dalam berusaha memperoleh informasi serta bertahan dalam menghadapi situasi sulit saat ia berada dalam kegiatan tertentu. Terdapat korelasi negatif antara self efficacydengan prokrastinasi akademik. Semakin tinggi self efficacymaka semakin rendah prokrastinasi akademik terjadi, sebaliknya bila semakin tinggi self efficacymaka semakin rendah prokrastinasi akademik (Pratiwi \& Sawitri, 2015; Lastary \& Rahayu, 2018). Penelitian Endrianto (2014) yang menunjukkan adanya korelasi negatif antara self control dan prokrastinasi akademik.

Menghadapi fenomena penyebab prokrastinasi akademik diperlukan keyakinan mahasiswa terhadap kemampuannya untuk menghadapi permasalahan dan melakukan tindakan yang dibutuhkan dalam menyelesaikan tugas untuk mendapatkan hasil yang diharapkan. Keyakinan seseorang akan kemampuan yang 
dimiliki disebut dengan self efficacy. Self efficacymenurut Bandura (1997) adalah keyakinan seorang individu mengenai kemampuannya dalam mengorganisasi dan menyelesaikan suatu tugas yang diperlukan untuk mencapai hasil tertentu. Pengaruh self efficacypada cara berpikir individu akan mampu mengarahkan dorongan dan tindakan untuk mencapai suatu hasil yang bersifat positif bagi individu sendiri. Keyakinan seseorang terhadap kemampuan untuk mengerjakan tugas seringkali mempengaruhi perilaku yang dihasilkan untuk menyelesaikan tugas tersebut. Self efficacymahasiswa menentukan usaha yang dikeluarkan dan daya tahan seseorang untuk bertahan dalam menghadapi rintangan dan hambatan ketika menghadapi tugas-tugas mereka.

Terbukti self control juga menjadi salah satu faktor yang mempengaruhi prokrastinasi akademik. Self control yang dimiliki setiap individu berbeda-beda. Individu yang memiliki self control yang tinggi dapat menggunakan waktu yang tepat dalam mengarahkan perilaku atau tugas utama. Akan tetapi jika self control yang rendah maka individu akan melakukan prokrastinasi akademik. Goldfried dan Merbaum (dalam Ghufron \& Risnawati, 2010) mendefinisikan self control sebagai suatu kemampuan untuk menyusun, membimbing, mengatur dan mengarahkan bentuk perilaku yang dapat membawa individu ke arah konsekuensi positif. Self control juga menggambarkan keputusan individu yang melalui pertimbangan kognitif untuk menyatukan perilaku yang telah disusun untuk meningkatkan hasil dan tujuan tertentu seperti yang diinginkan.

Berdasarkan hasil studi awal yang ditemukan bahwa terdapat perilaku prokrastinasi akademik pada mahasiswa Universitas 17 Agustus 1945 Samarinda. Berdasarkan beberapa keterangan hasil wawancara peneliti menduga bahwa perilaku prokrastinasi akademik pada mahasiswa di Universitas 17 Agustus 1945 tersebut dipengaruhi oleh ketidakyakinan mahasiswa membuat mereka melakukan penundaan terhadap tugas, mahasiswa merasa kesulitan untuk mengerjakan tugas yang sulit. Persepsi setiap individu akan berbeda dalam memandang tingkat kesulitan dari tugas tersebut. Hal ini mengindikasikan bahwa self efficacyyang rendah dapat mempengaruhi prokrastinasi akademik dan mahasiswa dengan sengaja menghabiskan waktu untuk melakukan kegiatan lain yang lebih menyenangkan sehingga mahasiswa tidak dapat mengontrol tindakannya dalam mengerjakan tugas tersebut. Hal ini mengindikasikan bahwa self control yang rendah dapat mempengaruhi prokrastinasi akademik.

Berdasarkan penjelasan tersebut, penelitian yang akan dilakukan oleh peneliti berbeda dengan penelitian sebelumnya, dalam penelitian ini peneliti melihat adanya pengaruh self efficacydan self control terhadap prokrastinasi akademik pada mahasiswa. Perbedaan lainnya adalah subyek dan tempat penelitian, dimana peneliti melakukan penelitian pada mahasiswa Universitas 17 Agustus 1945 Samarinda. Hipotesis dalam penelitian ini adalah terdapat pengaruh self efficacydan self control terhadap prokrastinasi akademik pada mahasiswa Universitas 17 Agustus 1945 Samarinda. Mahasiswa sebagai seseorang yang menuntut ilmu di perguruan tinggi, dituntut untuk dapat menjalani proses akademik agar mampu berprestasi secara optimal. Namun, mahasiswa sering kali dihadapkan dengan perkuliahan, baik itu tugas akademik ataupun non akademik. Tugas akademik yaitu jenis tugas formal yang berhubungan dengan akademik, misalnya tugas kuliah seperti membuat laporan/paper, menyiapkan powerpoint untuk persentasi tugas kuliah dan membaca. Sedangkan tugas non akademik adalah jenis tugas yang berhubungan dengan kegiatan sehari-hari, misalnya pekerjaan rumah, mengikuti organisasi, dan bekerja (Ferrari, dalam Chintia, 2017).

Banyaknya tugas kuliah menjadi penyebab konsentrasi mahasiswa berkurang terhadap tugas-tugas yang seharusnya diselesaikan tepat sehingga justru banyak mahasiswa yang menunda-nunda untuk menyelesaikannya. Kondisi seperti ini disebut dengan prokrastinasi dalam bidang akademik. Solomon dan Rothblum (dalam Gufron \& Risnawati, 2010) menjelaskan bahwa suatu penundaan dikatakan sebagai prokrastinasi apabila penundaan itu dilakukan pada tugas yang penting, dilakukan berulang-ulang secara sengaja, menimbulkan perasaan tidak nyaman, 
serta secara subyektif dirasakan oleh prokrastinator.

Prokrastinasi akademik penting untuk diteliti karena berpotensi menghambat proses pembelajaran dan prokrastinasi akademik yang dilakukan mahasiswa akan menimbulkan dampak negatif pada prestasi yang akan diraih (You, 2015). Prokrastinasi akademik pada mahasiswa dapat menghambat mereka untuk menyelesaikan suatu mata kuliah tertentu. Semakin lama mereka menunda maka semakin lama pula mereka untuk menyelesaikan tugas mata kuliah tertentu (Pratiwi \& Sawitri, 2015). Prawitasari(2012) mengungkapkan bahwa penundaan-penundaan yang terus-menerus dilakukan akan berakibat fatal, misalnya kegagalan memperoleh gelar sarjana, dan keterlambatan penyelesaian kuliah sehingga terjadi biaya penambahan kuliah. Secara materiil penundaan sering kali diikuti oleh perasaan bersalah, marah dan tidak berguna.

Dalam beberapa penelitian terdahulu yang dilakukan oleh Avico dan Mujidin (2014) menunjukkan bahwa konformitas yang tinggi dapat meningkatkan individu untuk melakukan prokrastinasi akademik sebaliknya jika konformitas rendah maka prokrastinasi akademik pada mahasiswa juga rendah. Selain konformitas, pengasuhan orang tua juga dapat mempengaruhi sesorang untuk melakukan prokrastinasi akademik, hal ini dibuktikan dengan penelitian yang dilakukan oleh Rosani \& Indrawati (2018) bahwa terdapat hubungan positif yang signifikan antara pola asuh otoriter dengan prokrastinasi akademik pada mahasiswa. Semakin positif persepsi pola asuh otoriter terhadap orangtua maka akan semakin tinggi prokrastinasi akademik yang dilakukan mahasiswa begitupun sebaliknya. Hasil penelitian Kadi (2016) terdapat hubungan kepercayaan diri dan self regulated learning terhadap prokrastinasi akademik pada Mahasiswa. Mahasiswa dengan kepercayaan diri yang rendah maka prokrastinasi akademik semakin tinggi artinya individu kurang yakin dengan pilihan dan kemampuan dalam mengerjakan tugas, begitupun sebaliknya mahasiswa yang memiliki kepercayaan diri yang tinggi maka prokrastinasi semakin rendah artinya individu yakin dengan pilihan dan kemampuan dalam mengerjakan tugas.
Tingkat keyakinan yang dimiliki seseorang dapat mendorongnya untuk meningkatkan kemampuan dalam berusaha memperoleh informasi serta bertahan dalam menghadapi situasi sulit saat ia berada dalam kegiatan tertentu. Terdapat korelasi negatif antara self efficacydengan prokrastinasi akademik. Semakin tinggi self efficacymaka semakin rendah prokrastinasi akademik terjadi, sebaliknya bila semakin tinggi self efficacymaka semakin rendah prokrastinasi akademik (Pratiwi \& Sawitri, 2015; Lastary \& Rahayu, 2018). Penelitian Endrianto (2014) yang menunjukkan adanya korelasi negatif antara self control dan prokrastinasi akademik.

Menghadapi fenomena penyebab prokrastinasi akademik diperlukan keyakinan mahasiswa terhadap kemampuannya untuk menghadapi permasalahan dan melakukan tindakan yang dibutuhkan dalam menyelesaikan tugas untuk mendapatkan hasil yang diharapkan. Keyakinan seseorang akan kemampuan yang dimiliki disebut dengan self efficacy. Self efficacymenurut Bandura (1997) adalah keyakinan seorang individu mengenai kemampuannya dalam mengorganisasi dan menyelesaikan suatu tugas yang diperlukan untuk mencapai hasil tertentu. Pengaruh self efficacypada cara berpikir individu akan mampu mengarahkan dorongan dan tindakan untuk mencapai suatu hasil yang bersifat positif bagi individu sendiri. Keyakinan seseorang terhadap kemampuan untuk mengerjakan tugas seringkali mempengaruhi perilaku yang dihasilkan untuk menyelesaikan tugas tersebut. Self efficacy mahasiswa menentukan usaha yang dikeluarkan dan daya tahan seseorang untuk bertahan dalam menghadapi rintangan dan hambatan ketika menghadapi tugas-tugas mereka.

Terbukti self control juga menjadi salah satu faktor yang mempengaruhi prokrastinasi akademik. Self control yang dimiliki setiap individu berbeda-beda. Individu yang memiliki self control yang tinggi dapat menggunakan waktu yang tepat dalam mengarahkan perilaku atau tugas utama. Akan tetapi jika self control yang rendah maka individu akan melakukan prokrastinasi akademik. Goldfried dan Merbaum (dalam Ghufron \& Risnawati, 2010) 
mendefinisikan self control sebagai suatu kemampuan untuk menyusun, membimbing, mengatur dan mengarahkan bentuk perilaku yang dapat membawa individu ke arah konsekuensi positif. Self control juga menggambarkan keputusan individu yang melalui pertimbangan kognitif untuk menyatukan perilaku yang telah disusun untuk meningkatkan hasil dan tujuan tertentu seperti yang diinginkan.

Berdasarkan hasil studi awal yang ditemukan bahwa terdapat perilaku prokrastinasi akademik pada mahasiswa Universitas 17 Agustus 1945 Samarinda. Berdasarkan beberapa keterangan hasil wawancara peneliti menduga bahwa perilaku prokrastinasi akademik pada mahasiswa di Universitas 17 Agustus 1945 tersebut dipengaruhi oleh ketidakyakinan mahasiswa membuat mereka melakukan penundaan terhadap tugas, mahasiswa merasa kesulitan untuk mengerjakan tugas yang sulit. Persepsi setiap individu akan berbeda dalam memandang tingkat kesulitan dari tugas tersebut. Hal ini mengindikasikan bahwa self efficacyyang rendah dapat mempengaruhi prokrastinasi akademik dan mahasiswa dengan sengaja menghabiskan waktu untuk melakukan kegiatan lain yang lebih menyenangkan sehingga mahasiswa tidak dapat mengontrol tindakannya dalam mengerjakan tugas tersebut. Hal ini mengindikasikan bahwa self control yang rendah dapat mempengaruhi prokrastinasi akademik.

Berdasarkan penjelasan tersebut, penelitian yang akan dilakukan oleh peneliti berbeda dengan penelitian sebelumnya, dalam penelitian ini peneliti melihat adanya pengaruh self efficacydan self control terhadap prokrastinasi akademik pada mahasiswa. Perbedaan lainnya adalah subyek dan tempat penelitian, dimana peneliti melakukan penelitian pada mahasiswa Universitas 17 Agustus 1945 Samarinda. Hipotesis dalam penelitian ini adalah terdapat pengaruh self efficacydan self control terhadap prokrastinasi akademik pada mahasiswa Universitas 17 Agustus 1945 Samarinda.

\section{METODE}

Sampel dalam penelitian ini adalah mahasiswa Universitas 17 Agustus 1945
Samarinda angkatan 2016,2017 dan 2018 dan masih aktif mengikuti kelas perkuliahan. Teknik pengambilan sampel yang digunakan dalam penelitian ini adalah teknik probability sampling dengan menggunakan proportionate stratified random sampling. Total sampel sebesar 320 mahasiswa Universitas 17 Agustus 1945 Samarinda.

Penelitian ini menggunakan pendekatan kuatitatif. Pengumpulan data menggunakan jenis penelitian survey dengan menggunakan pertanyaan terstruktur/ sistematis yang sama kepada banyak orang, untuk kemudian seluruh jawaban yang diperoleh penelitian dicatat, diolah dan dianalisis. Untuk mendapatkan data tentang pengaruh self efficacydan self control terhadap prokrastinasi akademik dalam penelitian ini maka digunakan skala sebagai alat ukur.

Alat ukur prokrastinasi akademik pada mahasiswa dalam penelitian ini disusun berdasarkan teori prokrastinasi akademik milik Ferarri (dalam Ghufron \& Risnawati, 2010) dikembangkan oleh Pratiwi (2015). Sedangkan alat ukur self efficacypada mahasiswa dalam penelitian ini disusun berdasarkan teori self efficacymilik Bandura (1997) yang dikembangkan oleh Engkizar (2014). Pengukuran terhadap self control diukur menggunakan skala self control Averill (dalam Ghufron \& Risnawati, 2010) yang terdiri atas 3 aspek yaitu, kontrol perilaku (behavior control), kontrol kognitif (cognitive control) dan mengontrol keputusan (decesional control).

Pengukuran dalam penelitian ini untuk melihat pengaruh self efficacydan self control terhadap prokrastinasi akademik pada mahasiswa, maka peneliti menggunakan teknik analisa regresi berganda

\section{HASIL}

Tabel 1 Kategori Skala Prokrastinasi Akademik

\begin{tabular}{lll}
\hline Kategori & F & \% \\
\hline Sangat Tinggi & 12 & $16,4 \%$ \\
Tinggi & 67 & $20,9 \%$ \\
Sedang & 165 & $51,6 \%$ \\
Rendah & 73 & $22,8 \%$ \\
Sangat Rendah & 3 & $9 \%$ \\
\hline
\end{tabular}


Berdasarkan tabel diatas, dapat diketahui bahwa 12 orang $(16,4 \%)$ memiliki prokrastinasi yang tergolong sangat tinggi, 67 orang $(20,9 \%)$ memiliki prokrastinasi akademik tergolong tinggi, 165 orang $(51,6 \%)$ tergolong sedang, 73 orang $(22,8 \%)$ tergolong rendah dan 3 orang $(9 \%)$ tergolong sangat rendah. Mean yang diperoleh adalah 57,64. Berdasarkan kategori diatas, dapat disimpukan bahwa rata-rata mahasiswa Universitas 17 Agustus 1945 cenderung memiliki prokrastinasi akademik pada tingkat sedang.

Tabel 2 Kategori Skala Self Efficacy

\begin{tabular}{lll}
\hline Kategori & F & \% \\
\hline Sangat Tinggi & 5 & $1,6 \%$ \\
Tinggi & 74 & $23,1 \%$ \\
Sedang & 87 & $27,2 \%$ \\
Rendah & 154 & $48,1 \%$ \\
Sangat Rendah & 0 & $0 \%$ \\
\hline
\end{tabular}

Berdasarkan tabel diatas, dapat diketahui bahwa 5 orang $(1,6 \%)$ memiliki self efficacy yang tergolong sangat tinggi, 74 orang $(23,1 \%)$ memiliki self efficacy tergolong tinggi, 87 orang $(27,2 \%)$ tergolong sedang, 154 orang $(48,1 \%)$ tergolong rendah dan tidak ada yang tergolong kategori sangat rendah. Mean yang diperoleh adalah 69,33. Berdasarkan kategori diatas, dapat disimpulkan bahwa rata-rata mahasiswa Universitas 17 Agustus 1945 Samarinda cenderung memiliki self efficacy pada tingkat rendah.

Tabel 3 Kategori Skala Self Control

\begin{tabular}{|c|c|c|}
\hline Kategori & $\mathbf{F}$ & $\%$ \\
\hline $\begin{array}{ll}\text { Sangat } & \text { Tinggi }\end{array}$ & 3 & $9 \%$ \\
\hline Tinggi & 27 & $8,4 \%$ \\
\hline Sedang & 131 & $40,9 \%$ \\
\hline Rendah & 150 & $46,9 \%$ \\
\hline Sangat Rendah & 9 & $2,8 \%$ \\
\hline
\end{tabular}

Berdasarkan tabel diatas, dapat diketahui bahwa 3 orang (9\%) memiliki self control yang tergolong sangat tinggi, 27 orang $(8,4 \%)$ memiliki self control tergolong tinggi, 131 orang $(40,9 \%)$ tergolong sedang, 150 orang $(46,9 \%)$ tergolong rendah dan 9 orang $(2,8 \%)$ tergolong kategori sangat rendah. Mean yang diperoleh adalah 34,33. Berdasarkan kategori diatas, dapat disimpulkan bahwa rata-rata mahasiswa Universitas 17 Agustus 1945 Samarinda cenderung memiliki self control pada tingkat rendah.
Berdasarkan hasil uji asumsi diketahui bahwa hasil pengujian One-Sample KolmogorovSmirnov Test menunjukkan bahwa variabel self efficacy,self control dan prokrastinasi akademik nilai probabilitas ( $\mathrm{p}$ value) residul dalam penelitian ini memiliki nilai sebesar 0,200 >0,05, maka dapat disimpulkam bahwa data yang di uji berdistribusi normal. Sedangkan hasil linieritas variabel self efficacydengan prokrastinasi akademik diperoleh nilai deviation from linearity sebesar 0,113 ( $p>0,05)$. Begitupula hasil linieritas variabel self control dengan prokrastinasi akademik diperoleh nilai deviation from linearity sebesar 0,224 ( $\mathrm{p}>0,05)$. Maka dapat disimpulkan bahwa terdapat hubungan secara linier antara variabel self efficacydan self control dengan prokrastinasi akademik. hasil uji multikolinieritas variabel self efficacydan self control terhadap prokrastinasi akademik dengan nilai tolerance $0,908<0,1$ dan nilai VIF $1.101>$ 10 yang artinya tidak terjadi multikolinieritas.

Hasil analisis regresi linier berganda dengan menggunakan metode enter, diperoleh nilai $\mathrm{R}$ sebesar 0,632. Nilai $\mathrm{R}$ dalam regresi menunjukkan adanya korelasi antara variabel self efficacydan self control terhadap variabel prokrastinasi akademik. Korelasi antar variabel berada pada korelasi tinggi. Sedangkan untuk melihat pengaruh antara variabel self efficacydan self control terhadap prokrastinasi akademik ditunjukkan oleh nilai koefisien determinasi ( $R$ Square) sebesar 0,400 dengan taraf signifikasi sebesar $0,000(\mathrm{p}<0,05)$. Hal ini berarti bahwa secara bersama-sama self efficacydan self control memberikan pengaruh sebesar $40 \%$ terhadap prokrastinasi, dengan demikian hipotesis yang diajukan oleh peneliti dalam penelitian ini diterima. Sumbangan efektif masing-masing antara self efficacyterhadap prokrastinasi akademik sebesar $24,9 \%$ dan self control terhadap prokrastinasi akademik sebesar $15,1 \%$.

\section{DISKUSI}

Hasil yang diperoleh dari uji hipotesis menunjukkan bahwa ada pengaruh negatif dan signifikan antara variabel self efficacy dan self control terhadap prokrastinasi akademik pada mahasiswa Universitas 17 Agustus 1945 Samarinda, dengan ini maka hipotesis dinyatakan 
diterima. Hasil tersebut ditunjukan oleh nilai $\mathrm{R}$ square sebesar 0,400 dengan signifikansi sebesar $0,000$ ( $\mathrm{p}<0,05)$. Hal ini menunjukkan bahwa semakin tinggi self efficacy dan self control maka semakin rendah prokrastinasi akademik begitupula sebaliknya semakin rendah self efficacy dan self control maka semakin tinggi prokrastinasi akademik.

Hasil penelitian ini serupa dengan hasil penelitian yang dilakukan oleh Lastary dan Rahayu (2018) bahwa terdapat korelasi negatif antara self efficacy dengan prokrastinasi akademik. Semakin tinggi self efficacy maka semakin rendah prokrastinasi akademik terjadi, sebaliknya bila semakin tinggi self efficacy maka semakin rendah prokrastinasi akademik. Hal tersebut sesuai dengan pendapat yang dikemukakan oleh Al Heilat, dkk (2014) kesulitan dalam mengerjakan tugas akademik ini maka dengan adanya self efficacy, mahasiswa tersebut bisa memilih aktivitas yang dapat memotivasinya untuk menyelesaikan tugasnya yaitu tidak melakukan penundaan. Sehingga dengan adanya keyakinan diri dan harapan keberhasilan yang tinggi membuat seseorang memiliki keinginan yang tinggi untuk mencapai keberhasilan, hal tersebut dapat dimaknai semakin rendah self efficacy maka semakin tinggi tingkat prokrastinasi akademik dan begitupula sebaliknya ( Hapsari,2016).

Keyakinan seseorang terhadap kemampuan untuk mengerjakan tugas seringkali mempengaruhi perilaku yang dihasilkan untuk menyelesaikan tugas tersebut. Hal ini sejalan dengan kutipan wawancara awal yang dilakukan peneliti, dimana perilaku penundaan yang dilakukan mahasiswa karena merasa kesulitan untuk mengerjakan tugas yang sulit. Persepsi setiap individu akan berbeda dalam memandang tingkat kesulitan dari tugas tersebut.

Oleh sebab itu, penting bagi mahasiswa untuk memiliki self efficacy dalam dirinya. Mahasiswa yang memiliki self efficacy rendah akan merasa sulit untuk memotivasi dirinya sehingga dapat mengurangi usahanya dalam penyelesaian tugas yang sedang dihadapi, individu juga tidak merasa yakin mampu mengerjakan tugas. Individu yang memiliki self efficacy rendah kecenderungan untuk melakukan prokrastinasi akademik cenderung tinggi. Individu yang memiliki self efficacy tinggi kecenderungan untuk melakukan prokrastinasi akademik cenderung rendah. Sehingga individu akan termotivasi untuk belajar dengan keras dan giat dengan tujuan untuk dapat menyelesaikan tugas dengan baik. Hal ini didukung oleh pendapat Hapsari (2016) yang menyatakan kesulitan dalam mengerjakan tugas akademik maka dengan adanya self efficacy, mahasiswa tersebut dapat memotivasi untuk menyelesaikan tugasnya yaitu tidak melakukan penundaan.

Hasil penelitian ini juga sesuai dengan penelitian Endrianto (2014) yang menunjukkan adanya korelasi negatif antara self control dan prokrastinasi akademik. Ketika dihadapkan pada pilihan antara melakukan sesuatu yang menyenangkan sekarang namun baru dirasakan nanti, kemampuan individu untuk mengendalikan diri sangatlah berperan. Hal ini sejalan dengan wawancara awal yang dilakukan oleh peneliti, dimana mahasiswa dengan sengaja menghabiskan waktu untuk melakukan kegiatan lain yang lebih menyenangkan misalnya main $\mathrm{hp}$, nonton drama korea dan jalan dengan teman. Hal ini menunjukkan bahwa mahasiswa tersebut kurang dapat mengontrol dirinya untuk tetap mengerjakan tugas.

Hasil penelitian menunjukkan bahwa self efficacy dan self control faktor yang mempengaruhi prokrastinasi akademik pada mahasiswa Universitas 17 Agustus 1945 Samarinda. Sumbangan efektif yang diberikan oleh kedua variabel tersebut terhadap prokrastinasi akademik sebesar $40 \%$, sedangkan $60 \%$ dipengaruhi oleh faktor-faktor lain yang tidak diungkap dalam penelitian ini. Faktorfaktor lain yang mempengaruhi prokrastinasi akademik pada penelitian terdahulu yang dilakukan oleh Avico dan Mujidin (2014) yang menunjukkan konformitas yang tinggi dapat meningkatkan individu untuk melakukan prokrastinasi akademik sebaliknya jika konformitas rendah maka prokrastinasi akademik pada mahasiswa juga rendah.

Pengasuhan orang tua juga dapat mempengaruhi sesorang untuk melakukan prokrastinasi akademik. Hal ini dibuktikan dengan penelitian yang dilakukan oleh Rosani \& Indrawati (2018) bahwa terdapat hubungan positif yang signifikan antara pola asuh otoriter dengan prokrastinasi akademik pada mahasiswa. Semakin positif persepsi pola asuh otoriter 
terhadap orangtua maka akan semakin tinggi prokrastinasi akademik yang dilakukan mahasiswa. Sebaliknya semakin negatif persepsi pola asuh otoriter terhadap orang tua maka akan semakin rendah prokrastinasi akademik yang dilakukan mahasiswa. Hasil penelitian Kadi (2016) terdapat hubungan kepercayaan diri dan self regulated learning terhadap prokrastinasi akademik pada Mahasiswa. Mahasiswa dengan kepercayaan diri yang rendah maka prokrastinasi akademik semakin tinggi artinya individu kurang yakin dengan pilihan dan kemampuan dalam mengerjakan tugas, begitupun sebaliknya mahasiswa yang memiliki kepercayaan diri yang tinggi maka prokrastinasi semakin rendah artinya individu yakin dengan pilihan dan kemampuan dalam mengerjakan tugas.

Sesuai dengan yang dijelaskan Ferrari dan McCown (dalam Ghufron \& Risnawati,2010) terdapat dua faktor yang mempengaruhi prokrastinasi akademik yaitu faktor internal dan faktor eksternal. Pada faktor internal meliputi kondisi fisik dan psikologis individu. Self efficacy dan self control ini termasuk faktor psikologis pada individu.

\section{KESIMPULAN}

Berdasarkan hasil penelitian yang telah diperoleh, maka dapat disimpulkan bahwa: Pertama,Terdapat pengaruh antara self efficacy dan self control terhadap prokrastinasi akademik pada mahasiswa Universitas 17 Agustus 1945 Samarinda. Kedua, Self efficacy pada mahasiswa tergolong rendah. Hal ini membuktikan bahwa rata-rata mahasiswa memiliki keyakinan diri yang kurang baik dalam mengerjakan tugas. Ketiga, Self control pada mahasiswa tergolong rendah. Hal ini membuktikan bahwa rata-rata mahasiswa memiliki pengendalian yang kurang baik terhadap tugas yang akan dikerjakan.

Prokrastinasi akademik yang dimiliki mahasiswa Universitas 17 Agustus 1945 Samarinda tergolong sedang.

\section{DAFTAR PUSTAKA}

Avico, R.S. \& Mujidin.(2014). Hubungan Antara Konformitas dengan Prokrastinasi
Akademik pada Mahasiswa Bengkulu yang Bersekolah di Yogyakarta.Empathy. Jurnal Fakultas Psikologi, 2(2), 62-65.

Al Heilat, M.Q., Alsubhien, A.M., \& Al Qudah,M.F.(2014).The Relationship between the Academic Procrastination and Self-Efficacy among Sample of King Saud University Students. Jurnal of Education and Practice, 5(16), 101-111.

Alwisol. (2012). Psikologi Kepribadian. Umm Press Malang.

Arikunto, S. (2014). Prosedur Penelitian Suatu Pendekatan Praktik. Jakarta: Rineka Cipta.

Azwar, S. (2012). Reliabilitas dan Validitas. Yogyakarta: Pustaka Pelajar.

Bandura, A.(1997). Self Efficacy: The exercise of Control. New York: W.H. Freeman and Company.

Chintia, R.R. \& Kustanti, E.R. (2017). Hubungan Antara Konformitas Dengan Prokrastinasi Akademik Pada Mahasiswa. Jurnal Empati, 6(2), 31-37.

Damri, Engkizar \& Anwar, F. (2017). Hubungan Self Efficacy dan Prokrastinasi Akademik Mahasiswa dalam Menyelesaikan Tugas Perkuliahan. Jurnal Bimbingan Konseling. 3(1), 7495.

Endrianto, C. (2014). Hubungan Antara Self Control Dan Prokrastinasi Akademik Berdasarkan TMT. Jurnal Ilmiah Mahasiswa Universitas Surabaya, 3(1), $1-11$

Feist \& Feist. (2006). Theories of Personality. Yogyakarta: Pustaka Pelajar.

Ghufron, N.M. \& Risnawita, R. (2010). Teoriteori psikologi. Jogjakarta:Ar- Ruz Media. 
Hapsari, W.E. (2016). Self Efficacy Pengerjaan Skripsi Prokrastinasi Akademik dengan Mahasiswa Fakultas Farmasi Universitas Katolik Widya Mandala Surabaya. Jurnal Experienta, 4(2), 75-84.

Kadi, A.P.U. (2016). Hubungan Kepercayaan Diri Dan Self Regulated Learning Terhadap Prokrastinasi Akademik Pada Mahasiswa Psikologi 2013. eJournal Psikologi, 4(4), 457-471.

Lastary, D.L. \& Rahayu, A.(2018). Hubungan Dukungan Sosial Dan Self Efficacy Dengan Prokrastinasi Akademik Mahasiswa Perantau Yang Berkuliah di Jakarta. HUMANIORA, 2(2), 17-23.

Pratiwi, A.D. \& Sawitri, D.R. (2015). Prokrastinasi Akademik Ditinjau Dari Efikasi Diri Akademik Dan Lama Studi Pada Mahasiswa Jurusan Desain Komunikasi Visual Universitas Dian Nuswantoro. Jurnal Empati, 4(4), 272276.
Prawitasari. (2012). Psikologi Terapan: Melintas Batas Disiplin Ilmu. Jakarta: Erlangga.

Rosani, T., \& Indrawati, E. S. (2018). Hubungan Antara Pola Asuh Otoriter Dengan Prokrastinasi Akademik Pada Mahasiswa Angkatan 2013 Jurusan Ilmu Komunikasi Fakultas Ilmu Sosial Dan Ilmu Politik Universitas Diponegoro. Jurnal Empati, 7(2), 114-119.

Sugiono. (2018). Metode Penelitian kuantitatif, kualitatif dan $\mathrm{R}$ \& $\mathrm{D})$. Bandung : Alfabeta.

You, J.W. (2015). Examining the effect of academic procrastination on achievement using Ims data in elearning. Journal of Educational Technology \& Society, 18(3), 64-74. 